\title{
Az alkalmazott nyelvészek szakmai közösséggé formálódása a 20. század végén és a 21. század elején
}

\begin{abstract}
The emergence of a professional community in the late 20th and early 21st centuries
The Association of Hungarian Applied Linguists and Language Teachers (MANYE) is the biggest linguistic association in Hungary. The thirtieth anniversary of its founding is a suitable occasion to recall and analyse the documents relating to the circumstances of its establishment. The thirtyyear history of the association can be divided into three stages. The first was its coming of age (1990-1998); the second stage was consolidation (1999-2015), and the third was renewal (2016-). This study deals with the first two stages. Based on the comparative analysis of documents, it describes the launching of two initiatives in 1990, one from the language teaching community, the other from applied linguists, which ultimately led to the emergence of a professional community and a series of Hungarian applied linguistic conferences spanning 30 years.
\end{abstract}

Keywords: association, language teachers, applied linguists, Hungarian conferences of applied linguistics

A Magyar Alkalmazott Nyelvészek és Nyelvtanárok Egyesülete (MANYE) a legnagyobb létszámú és a legrégebben működő nyelvészeti egyesület Magyarországon. Megalakulásának 30. évfordulója méltó alkalom a visszaemlékezésre, és az alapítás körülményeiröl szóló dokumentumok elemzésére. Az egyesület harmincéves története három szakaszra bontható:

Első korszak: Az útkeresés időszaka (1990-1998)

Második korszak: A konszolidáció időszaka (1999-2015)

Harmadik korszak: Újabb útkeresés és megújulás időszaka (2016-)

A második és a harmadik korszak dokumentumai már szövegszerkesztővel készültek, elektronikusan jutottak el a tagsághoz, sok közülük megtalálható az egyesület honlapján (www.manye.hu), de az első korszak történetének feltárásához személyes emlékeimen és jegyzeteimen kívül olyan dokumentumok elemzésére volt szükség, amelyeknek egy része még mechanikus írógéppel készült, és nincs digitalizálva. Mivel az első korszak leírásakor párhuzamosan zajló eseményekről lesz szó, párhuzamosan elemeztem két dokumentumcsomagot. Az első csomag Gárdus Jánosnak (1932-1995), az egyesület első főtitkárának hagyatékából származó leveleket, meghívókat és jegyzőkönyveket tartalmaz (GJDOK 1-11), a második csomag a Magyar Tudományos Akadémia Alkalmazott Nyelvészeti Bizottságának 1990 és 1995 között keletkezett irataiból áll, ezek szintén meghívók, beszámolók és jegyzőkönyvek (MTADOK 1-9). Bár 
csak az 1990-1995-ös időszak iratait vizsgáltam, a vizsgált dokumentumok együttes terjedelme kb. 150 oldal, tehát ez az áttekintés szükségképpen vázlatos lesz, és sok minden kimarad belöle.

Az itt következő tanulmányban, amely a MANYE 30. évfordulója alkalmából tartott előadásom szerkesztett változata, csak a MANYE első két korszakával foglalkozom (1990-2015), a harmadik korszakról és a jövőbeni tervekről Prószéky Gábor és Seidl-Péch Olivia előadása szólt. Ugyancsak nem foglalkozom a MANYE életében fontos szerepet játszó Modern Nyelvoktatás címü folyóirattal, melyről Nádor Orsolya tartott részletes beszámolót.

\section{Az útkeresés időszaka (1990-1998)}

\section{Az elsó kezdeményezés (a nyelvtanári vonal)}

Az 1990. május 11-i dátumú első ülésen és a későbbi üléseken kitöltött belépési nyilatkozatok megsárgult lapjait olvasgatva (szám szerint 53 db, GJDOK2), valamint az alakuló ülés jegyzőkönyvét és a későbbi közgyülési jegyzőkönyveket lapozgatva, nagyon érdekes nyomon követni, ahogy szemünk láttára alakul a történelem, anélkül hogy jelenlévők tudnák, hogy történelmet írnak. És ez most nem túlzás. Már kevesen vagyunk azok közül, akik az első néhány év eseményeinek szinte mindegyikén részt vettek, és természetesen nem tudtuk, hogy történelmet írunk. Hogy egy olyan egyesületet alapítunk meg 1990-ben, amely még 2020-ban, harminc év múlva is aktívan fog müködni.

Sőt, mint a jegyzőkönyvből kiderül (GJDOK1), nem is a MANYE-t alapították meg a résztvevők 1990. május 11-én 11.00 és 13.00 között a TIT Bródy Sándor utcai székházának tanácstermében, hanem a Magyarországi Nyelvoktatók Egyesületét, bár annak rövidítése szintén MANYE lett volna, de akkor még senkinek nem jutott eszébe ez a rövidítés. Sőt az egyesület pontos neve is vita tárgya volt még egy jó ideig. A dokumentumok szerint 1994-ig. Erre majd még visszatérek. Ráadásul a vitás kérdésekben való megállapodás lehetősége is bizonytalan időre kitolódott, mert az alakuló ülés összehívója, dr. Szépe György, akit ezen az 1990. május 11-i alakuló ülésen a jelenlévők nyílt szavazással egyhangúlag megválasztottak az egyesület elnökének, azt is bejelentette, hogy 1990. augusztus 30-án elutazik Amerikába vendégtanárnak, és a főtitkárt, dr. Gárdus Jánost, a Miskolci Egyetem Nyelvi Intézetének vezetőjét bízta meg, hogy nyújtsa be az alapszabályt bejegyzés céljából a Miskolci Megyei Bíróságon, és ez meg is történt, mint ahogy azt a további Szépe-Gárdus-levélváltás igazolja (GJDOK3).

Itt tartott az egyik szálon elindult szervezkedés, amikor 1990 öszén egy másik, történetünk szempontjából fontos esemény is történt a Magyar Tudományos Akadémia Nádor utcai épületének első emeleti tanácstermében, az Alkalmazott Nyelvészeti Bizottság ülésén, amelyről az ott jelenlévők szintén nem is sejthették, hogy mennyire fontos eseményen vettek rész, és milyen messzire ható következményei lesznek a jövőre nézve (MTADOK1).

Mielőtt azonban erre rátérnénk, néhány körülmény tisztázása végett még vissza kell térnünk a Bródy Sándor utcába (GJDOK1). Az ott lezajlott alakuló ülés hatoldalas gépírásos jegyzőkönyvének ötödik oldalán azt olvassuk, hogy Szépe György „Felkéri 
a TIT Országos elnökségét, hogy az új egyesület bejegyzésének költségeit fedezzék". Hogy jön ide a TIT? Sőt, ha megnézzük a jegyzőkönyv címét, azt olvashatjuk, hogy „Jegyzőkönyv a Tudományos Ismeretterjesztő Társulat Országos Idegennyelv-oktatási Választmányának kibővített vezetőségi üléséről, amely egyúttal a Magyarországi Nyelvoktatók Egyesületének alakuló ülése".

A TIT úgy kerül a képbe, hogy Szépe György akkor a TIT alelnöke volt, és aktívan rész vett a TIT Országos Idegennyelv-oktatási Választmányának munkájában. A TIT Budapesti Nyelviskolája nemcsak nagy népszerüségnek örvendő idegen nyelvi tanfolyamokat tartott, hanem már a 70-es évektől kezdve nagy szerepet játszott az idegennyelv-tanárok szakmai továbbképzésében, folyamatosan rendezett nyelvoktatási és nyelvtudományi ismeretterjesztő konferenciákat, kiadta a Modern Nyelvoktatás címü folyóiratot, illetve a lila borítójú ősváltozatot, amely a mai Modern Nyelvoktatás elődje volt, és élénk könyvkiadási tevékenységet is folytatott, melynek célja az volt, hogy az idegennyelv-tanárok megismerkedjenek a modern nyelvtudomány eredményeivel. Telegdi Zsigmond, Kiefer Ferenc, Dezső László, Hegedủs József, Papp Ferenc, Petőfi S. János neve van a szerzők között, ez mutatja, hogy a legjobb nyelvészeknek adtak publikálási lehetőséget.

A rendszerváltást követően a TIT szervezeti átalakulása is megkezdődött, és Szépe György számára kézenfekvő volt, hogy a nyelvoktatók a TIT keretében önálló egyesületté alakuljanak, és ez az egyesület lássa el a továbbiakban az érdekképviseletüket, továbbképzésüket, adja ki a Modern Nyelvoktatást, tehát lássa el mindazokat a feladatokat, amit annak idején a TIT Idegennyelv-oktatási Szakosztályai elláttak. Mindezt részletesen kifejti az alakuló ülés jegyzőkönyvében (GJDOK1). Mindebből nyilvánvaló, hogy bár Szépe György mindig az alkalmazott nyelvészet lehető legtágabb értelmezését képviselte, a Magyarországi Nyelvoktatók Egyesületének megalapításával elsősorban a nyelvtanárok érdekképviseletét és továbbképzését tüzte ki célul.

\section{A második kezdeményezés (az alkalmazott nyelvészeti vonal)}

Térjünk vissza a Nádor utca 7.-be, ahol 1990. november 1-én a Magyar Tudományos Akadémia Alkalmazott Nyelvészeti Bizottsága ülésezett Papp Ferenc akadémikus elnöklésével. A laikus olvasó számára talán fel sem tűnik, hogy nem Munkabizottságról hanem Bizottságról van szó, pedig az alkalmazott nyelvészeti szakemberek számára nagy előrelépés volt a bizottsági státusz, amit az 1990-1993 és az 1993-1996 közötti ciklusban sikerült kiérdemelnie az alkalmazott nyelvészetnek, nyilván Papp Ferenc akadémikus szakmai súlyának köszönhetően. Az 1990. november 1-i ülésen a hároméves ciklus munkatervének kidolgozása volt a téma, és felvetődött egy olyan konferencia terve, amelyen az alkalmazott nyelvészet különböző területeit müvelők találkozhatnának (MTADOK 2).

A fordítástudománynak akkor már volt egy konferenciasorozata, amelyet az MTA Alkalmazott Nyelvészeti Munkabizottsága égisze alatt rendeztem a 80-as években (1983, 1984, 1985, 1986, 1988), és az anyaga meg is jelent a Fordításelméleti Füzetek címü kiadványban. Lengyel Zsolt egymás után rendezte a gyermeknyelvi konferenciákat, Gósy Mária a beszédkutatási konferenciákat, de nem volt olyan rendezvény, amelyen az összes alkalmazott nyelvész találkozott volna. Amely például hasonló lett 
volna a magyar nyelvészek változó helyszíneken rendezett kongresszusaihoz (1977 Nyíregyháza, 1983 Szombathely, 1988 Budapest).

Mikor éppen azt tárgyaltuk, hogy milyen időközökben lenne reális összehívni az alkalmazott nyelvészeket, Székely Gábor a Nyíregyházi Tanárképző Főiskola föigazgatója mindenki legnagyobb meglepetésére felajánlotta, hogy ő 1991 tavaszán megrendezi az első alkalmazott nyelvészeti konferenciát. Ez azért volt nagy meglepetés, mert szinte lehetetlen feladatnak tủnt 1990 novemberében elhatározni egy 1991. tavaszi országos nyelvészeti, illetve országos alkalmazott nyelvészeti konferencia megrendezését, annyira közeli volt ez a dátum.

Innen már nemcsak Gárdus János hagyatékának dokumentumaira támaszkodom, mert az MTA Alkalmazott Nyelvészeti Bizottsága titkáraként minden ülésről készítettem jegyzőkönyvet, és ezeknek nagy része az egymás után következő alkalmazott nyelvészeti konferenciák lebonyolításáról szóló beszámolókból állt. Az történt ugyanis, hogy az első, 1991-es sikeres nyíregyházi alkalmazott nyelvészeti konferencia után azonnal jelentkezett Lengyel Zsolt, hogy 1992-ben Szegeden megrendezi a másodikat (MTADOK 3), majd Gárdus János, hogy 1993-ban Miskolcon megrendezi a harmadikat (MTADOK 7). Később folytatom a sort, de ez a harmadik, mint látni fogjuk, döntő jelentőségủ lesz a MANYE története szempontjából.

\section{A két kezdeményezés közeledése}

Ha valaki figyelmesen követte az eddigieket, észrevehette, hogy két különböző helyről indult a kezdeményezés, amely a MANYE létrejöttéhez vezetett: hogy ne kelljen hoszszú intézményneveket mondani, mondjuk azt, hogy a Bródy Sándor utcából (TIT és Szépe György) és a Nádor utcából (MTA és Papp Ferenc). Az első az idegennyelv-tanárok felöl, a másik az alkalmazott nyelvészek különböző területeit (pszicholingvisztika, szociolingvisztika, lexikográfia, terminológia, fordítástudomány, számítógépes nyelvészet stb.) képviselő szakemberek felöl.

Az első alkalmazott nyelvészeti konferencia felhívását és egyben jelentkezési lapját még postán küldtük ki kb. 600 címre 1990 őszén és 1990 tavaszán. Nekem volt egy regiszteres füzetem, a magyar egyetemek és föiskolák lektorátusain és nyelvi tanszékein dolgozó kollégák nevével, az akkor már müködő magánnyelviskolák címével, de még a középiskoláknak, sőt az óvodai nyelvoktatásban részt vevőknek is küldtünk meghívót. Az MTA Alkalmazott Nyelvészeti Munkabizottsága állta a sokszorosítás költségét és a postaköltséget, azaz a borítékokat kisebb adagokban leadhattam a Nádor utca 7.-ben található postázóba.

A jelentkezések már a nyíregyházi, akkor még Bessenyei György Tanárképző Főiskolára futottak be, ahol nagy meglepetést okozott a jelentkezők nagy száma, ami több mint 400 fö volt, száznál több előadással. E-mail kapcsolat akkor még nem volt. Szerencsére féléves amerikai tartózkodásnak köszönhetően nekem már volt szövegszerkesztőm, és mikor Székely Gábor felhozta Budapestre a jelentkezési lapokat (már szekciókba csoportosítva), azon tudtam elkészíteni a programfüzetet. A konferenciaanyagot viszont még nem lehetett szövegszerkesztővel készíteni, mert az előadók nagy része mechanikus írógéppel írta meg az előadást, és aki már szövegszerkesztővel készítette, az sem tudta e-mailen küldeni. Mindezt ma már nehéz elképzelni. 
Az előadásokat az előadók papíron adták le, vagy postán küldték el, és a szerkesztők egyszerüen befényképezték a kötetbe (Székely, 1992). Így aztán az Első Magyar Alkalmazott Nyelvészeti Konferencia előadásai igen szerény kivitelezésủ kiadványban jelentek meg, de a lényeg az, hogy a következő konferenciára megjelentek, és ezt a szokást az elmúlt 30 év alatt is megőriztük. A technikai fejlődéssel a kiadványok színvonala egyre magasabb lett, de erre még visszatérek.

\section{Az elsô három alkalmazott nyelvészeti konferencia jellemzôi}

Melyek voltak az első három konferencia jellemző vonásai? Az első: az ingyenesség. Bár erre talán már kevesen emlékeznek, az első három konferencián nem volt részvételi díj. A második: a rövidség. Mindhárom konferencia kétnapos volt: péntek délben kezdődött, és szombaton kora délután végződött (1991. május 3-4., 1992. május 2-3., 1993. április 2-3.). A harmadik jellegzetesség az átfogó tematika. Két értelemben is: a témák köre az alkalmazott nyelvészet legszélesebb körét ölelte fel, és a nyelvoktatás összes szintjére és színterére kiterjedt az óvodai nyelvoktatástól az egyetemi nyelvoktatáson keresztül a magánnyelviskolákban folyó nyelvoktatásig. A negyedik jellegzetesség: a dokumentáltság. Minden konferencia anyaga megjelent a következő konferenciára. Az ötödik jellegzetesség a folyamatosság: minden konferencia végén akadt jelentkező a következő konferencia megrendezésére. És végül, a hatodik jellegzetesség: a nagy létszám. A résztvevők száma mindhárom konferencián 400 körül volt. Az előadók száma egyre nőtt, Nyíregyházán 160 (MTADOK 4), Szegeden 175 (MTADOK 5, 6), Miskolcon 200 (MTADOK 7) elöadás hangzott el. Ebből következett a párhuzamos szekciók nagy száma is.

Mindegyik konferenciának volt egy nagyon általános központi témája (pl. a Budapesti Müszaki Egyetemen 1994-ben: Többnyelvüség az oktatásban és a kutatásban), de mivel éppen az volt a cél, hogy az alkalmazott nyelvészek találkozzanak, és tudomást szerezzenek egymás eredményeiről, az alkalmazott nyelvészet egyik területét sem zárhattuk ki. Sőt, azt sem akartuk, hogy csak az idegen nyelvek oktatói érezzék magukénak ezeket a konferenciákat, hiszen az anyanyelv oktatásának éppen úgy vannak alkalmazott nyelvészeti vonatkozásai, a magyar mint idegen nyelv oktatásáról nem is beszélve. Mindegyik konferencián más volt a szekciók sorrendje és elnevezése. Mivel a szekcióbeosztást az egyes témákból jelentkezők száma és a helyi lehetőségek (előadótermek nagysága és felszereltsége) is befolyásolta, nem lenne értelme mindegyik konferencia szekcióit külön felsorolni, inkább hat nagyobb egység köré rendezem a témákat, melyek néha azonos, néha különböző kisebb szekciókban szerepeltek:

1. Nyelvtanárképzés

2. Az idegennyelv-oktatás módszertana (minden szinten)

3. Szaknyelvoktatás, szaknyelvkutatás, terminológia, lexikográfia

4. Pszicholingvisztika, szociolingvisztika

5. Anyanyelvi nevelés, magyar mint idegen nyelv, nyelvmüvelés

6. Fordítás, tolmácsolás, kontrasztív nyelvészet, számítógépes nyelvészet

Ebben a felsorolásban nem véletlenül áll a nyelvtanárképzés az első helyen. Szépe György a miskolci III. Alkalmazott Nyelvészeti Konferencián tartott plenáris elöadá- 
sában arról beszélt, hogy az összes alkalmazott nyelvészeti területet a nyelvtanárképzés szolgálatába kell állítani.

„Egy olyan tárgy esetében mint a földrajz, a fizika, vagy akár a történelem, az átadandó alap-diszciplína nem »ér össze« saját anyagának tanításával, nem alkot vele egy kontinuumot. A nyelvi tárgyak esetében megvan ez a kontinuum. S az egyetlen keret, amelyben ez igazán kibontakozhat: az alkalmazott nyelvészet" (Szépe, 1994. p. 27)

Véleménye szerint „A jövendő nyelvtanár müveltségében központi helyet kellene elfoglalnia a fenti értelemben vett alkalmazott nyelvészetnek” (i. m. 28), továbbá „valamennyi olyan intézményben (egyetemen és föiskolán), ahol nyelvtanárokat képeznek ki, szükség van külön alkalmazott nyelvészeti tanszékekre" (i. m. 28). Ez a szemlélet nagyon közel állt a hallgatósághoz, hiszen több egyetemen és fóiskolán éppen akkor, a 90-es években alakultak az alkalmazott nyelvészeti tanszékek (Miskolc, Szeged, Szombathely) és próbálkoztak az önálló alkalmazott nyelvészeti szak akkreditációjával.

Miért beszélünk ilyen hosszan az első három alkalmazott nyelvészeti konferenciáról, mikor utána még 25 következett? Azért, mert meggyőződésem, hogy lényegében itt dőlt el, hogy lesz-e folytatás. És lett folytatás, bár mindjárt az első két jellegzetesség, az ingyenesség és a kétnapos időtartam a későbbiekben megváltozott, de hogy a három konferencián jelen lévő alkalmazott nyelvészeti szakterületek összetartoznak, és kölcsönösen tanulhatnak egymástól, az itt vált nyilvánvalóvá. Miként az is, hogy a nyelvtanárok és az alkalmazott nyelvészek azonos szakmai közösséghez tartoznak.

\section{Mi történt közben a Magyarországi Nyelvoktatók Egyesületében?}

Miközben az MTA Alkalmazott Nyelvészeti Bizottságának titkári jelentéseiben részletes beszámolókat (MTADOK 4, 5, 6, 7) olvashatunk az első három alkalmazott nyelvészeti konferencia sikeres megrendezéséről, arról, hogy mi történt 1990 és 1993 között a Magyarországi Nyelvoktatók Egyesületében, hiányosak a dokumentumaink. Rendelkezésünkre áll Gárdus János fötitkár meghívója (GJDOK 4) a Magyarországi Nyelvoktatók Egyesületének kibővített vezetőségi ülésére, melynek témája az 1991-1993-ig terjedő időszak munkatervi vitája volt, de a munkatervi vitáról sajnos nincs jegyzőkönyvünk. Viszont van jegyzőkönyvünk az 1993. október 29-i közgyülésről, amelyben nem sok jót olvashatunk az egyesület eddigi müködéséről (GJDOK 5).

Gárdus János főtitkári beszámolója az egyesület elmúlt hároméves tevékenységét ismertetve megállapítja, hogy ez az időszak nem volt sikeres: nem halad a tagtoborzás, nincs anyagi és adminisztratív támogatás. Mivel a TIT-ben az idegennyelv-oktatás megszünt, a TIT támogatására már nem lehet számítani, a tagság pedig még nem fizet tagdíjat. Mint a beszámolóból kiderül, az is gond, hogy a rendszerváltás után hirtelen sok másik új nyelvtanári egyesület is megalakult hasonló névvel pl. NYOE (Nyelvtanárok Országos Egyesülete) és nehéz megkülönböztetni őket (GJDOK 5).

A Magyarországi Nyelvoktatók Egyesületében tehát nem alakultak kedvezően az események. Szépe György, az egyesület elnöke, aki nem sokkal a tavaszi miskolci konferencia előtt tért vissza külföldi tartózkodásából, ezen az októberi közgyülésen csak 
rövid beszámolót tartott, amely inkább a jövőbeli tervekről szólt. A két beszámolót vita követte, amelyhez sokan hozzászóltak. A hozzászólások lényege, hogy ne forgácsoljuk szét az erőinket, akik tenni akarnak valamit a nyelvoktatás színvonaláért, azoknak öszsze kell fogniuk, az egyesületnek olyan nevet kell adni, ami jól megkülönböztethető a többitől, és jó példaként említik többen is az MTA Alkalmazott Nyelvészeti Bizottsága által szervezett első három alkalmazott nyelvészeti konferencia sikerét, sőt ekkor már lehetett tudni, hogy a Budapesti Müszaki Egyetem vállalkozik a negyedik alkalmazott nyelvészeti konferencia megrendezésére 1994 tavaszán (GJDOK 5, MTADOK 8).

Az 1994 áprilisában tartott vezetőségi ülésen Szépe György két javaslatot tett az egyesület nevével kapcsolatban:

(i) Válassza az egyesület névadóul Brassai Sámuelt (ez a nemzetközi kapcsolatok szempontjából jelenthet hátrányt).

(ii) Fejezze ki nevében is, hogy a magyarországi nyelvtanárok minél szélesebb körét kívánja az egyesület összefogni (ezt a törekvést a Magyar Alkalmazott Nyelvészek és Nyelvtanárok Egyesülete elnevezés látszik legjobban kifejezni) (GJDOK 6).

Mint láthatjuk, itt jelenik meg elöször az új név javaslatként, amelyet majd az 1994 májusában tartandó közgyülésen kell a tagságnak elfogadnia.

\section{A MANYE név megszületése}

A Magyarországi Nyelvoktatók Országos Egyesületének 1994 májusában tartott közgyűlését joggal nevezhetjük történelmi jelenőségü eseménynek a MANYE életében. Erről az eseményről szerencsére részletes jegyzőkönyv áll rendelkezésünkre (GJDOK 7). Ennek alapján elmondhatjuk, hogy a résztvevők még mint a Magyarországi Nyelvoktatók Országos Egyesületének tagjai léptek be a SOTE Nagyvárad téri toronyházának aulájába, ahol a közgyülést meghirdették, de már mint MANYE-tagok léphettek ki. A közgyülés fó napirendi pontja az alapszabály módosítása volt, mivel azt ki kellett egészíteni egy politikamentességi nyilatkozattal. És ha már hozzá kellett nyúlni az alapszabályhoz, felmerült egy szerencsésebb név választásának lehetősége is. Íme, a három módosítás, és köztük az első az új név és az új rövidítés.

- Az 1. fejezet 1. paragrafusa 2. mondatának új szövege: Az egyesület hivatalos nyelve a magyar; körbélyegzöjének szövege: Magyar Alkalmazott Nyelvészek és Nyelvtanárok Egyesülete; betüvel rövidítve MANYE (vagyis nagyobb méretü NY betüvel írandó).

- Az 1. fejezet 2. paragrafusa 1. mondatának új szövege: Az egyesület célja elösegíteni az alkalmazott nyelvészetet, különösképpen az idegen nyelveknek (beleértve a magyarnak mint idegen nyelvnek) magyarországi kutatását, oktatását, elterjesztését;

- Az 1. fejezet 2. paragrafusa utolsó mondatának új szövege: Az egyesület múködése semmilyen formában nem érint politikai, vallási kérdéseket, ezek áttételesen sem tárgyai, témái a MANYE által szervezett rendezvényeknek (GJDOK 7).

A következő dokumentum arról tanúskodik, hogy az elnök már az új néven hívja össze a Magyar Alkalmazott Nyelvészek és Nyelvtanárok Egyesületének 1994. november 22-i titkársági ülését (GJDOK 8). 
Ez a hiteles története a MANYE név megszületésének, és mivel a jegyzőkönyvek alapján bizonyítottnak tekinthető, hogy nem új egyesületről, hanem csak névmódosításról van szó, nyugodtan tekinthetjük 1990-t az alapítás évének, ezért ünnepeljük 2020-ban a 30. évfordulót. Az eddig elmondottak viszont magyarázatot adnak arra, hogy miért van némi bizonytalankodás az alapítás éve körül.

A rövidítés eleinte nem egyforma méretű betűkből állt. A nagyobb méretű „,M” betüt egy kisebb méretü „A” betü követte, majd újra egy nagyobb méretü „NY” betü következett, mely a Nyelvészek és Nyelvtanárok együttesét volt hivatott jelképezni, majd megint egy kisméretü „E” betü következett: MANYE (sic!). A különböző betüméret a további jegyzőkönyvekben egy ideig még szerepel (GJDOK 9-11), de az 1997-es dokumentumokban már nem találkozunk vele, és az 1998-ban elfogadott végleges logó tervében már egyforma méretü betűk szerepelnek.

Az 1994. májusi közgyủlésnek a jegyzőkönyve nemcsak a MANYE név megszületéséről tanúskodik, hanem az egyesület és az MTA Alkalmazott Nyelvészeti Bizottsága által indított alkalmazott nyelvészeti konferenciasorozat összekapcsolódásáról is, mivel megtudjuk belöle, hogy a közgyülés végén Szépe György javasolja, hogy az egyesület következő közgyülését Veszprémben az V. Magyar Alkalmazott Nyelvészeti Konferencia alkalmával hívjuk össze (GJDOK 7), és ezzel egy máig is múködő hagyományt teremtett meg. Ezt a szokást követjük mind a mai napig.

\section{Az útkeresés idószakának vége: a két kezdeményezés találkozása}

Ettől kezdve természetes volt, hogy az MTA Alkalmazott Nyelvészeti Bizottsága (1996 után újra Munkabizottsága) és a Magyar Alkalmazott Nyelvészek és Nyelvtanárok Egyesülete egyaránt szerepel az évente megrendezett alkalmazott nyelvészeti konferenciák szervezői között az évenként változó egyetemek és főiskolák mellett. Mindkét szervezet delegált tagokat a változó helyi szervezőbizottságokba. A MANYE rövidítés viszont nem honosodott meg ilyen gyorsan. 1994 és 1997 között még nem szerepel sem a konferenciák nevében, sem a konferenciakötetek címlapján.

A konferenciák elnevezésében kezdetben okozott egy kis problémát a „magyar” jelző, mert többen úgy vélték, hogy így ezek magyar nyelvészeti konferenciák, és csak a magyar nyelvészeknek szólnak.

Nyilvánvalóan ez az oka annak, hogy az 1994-ben a Budapesti Műszaki Egyetem által szervezett konferencia elnevezéséből a szervezők kihagyták a „magyar” szót, a konferenciát IV. Országos Alkalmazott Nyelvészeti Konferencia címmel hirdették meg (MTADOK 8), és a konferenciakötet is ezzel a címmel jelent meg (Aradi, Sturcz \& Szöllősy, 1995). Az útkeresés jele, hogy 1995-ben az ötödik konferencia szervezője, Lengyel Zsolt visszatért az eredeti címhez, és a veszprémi konferenciát az V. Magyar Alkalmazott Nyelvészeti Konferencia címmel hirdette meg (MTADOK 9). Így szerepel a név a konferenciakötet borítóján is (Lengyel \& Navracsics, 1996). A hatodik alkalmazott nyelvészeti konferencia nevében viszont újra az „országos” jelző szerepel: a VI. Országos Alkalmazott Nyelvészeti Konferencia elnevezéssel hirdették meg, és így jelent meg a konferencia anyaga is (Székely \& Cs. Jónás, 1996). Ugyancsak az „országos” jelző szerepel az 1997-ben a Külkereskedelmi Főiskolán tartott VII. Országos Alkalmazott Nyelvészeti Konferencia nevében, és kötetének címében is (Polyák, 1998). 
Ezen a konferencián elhangzott egy figyelemre méltó összefoglalás az eddigi konferenciák tematikájáról. Hidasi Judit Az alkalmazott nyelvészeti konferenciák színeváltozása címmel áttekintette az elmúlt hét év alkalmazott nyelvészeti konferenciái tematikájának változását. Véleménye szerint minden alkalmazott nyelvészeti konferencián vannak örökzöld témák (pl. szaknyelvoktatás, számítógépes nyelvészet, fordítás, tolmácsolás), vannak aktuális nyelvpolitikai döntésekkel összefüggő témák (ilyen volt 1991-ben az orosznyelv-tanárok átképzése), és mindig vannak divatos témák, amelyek az új alkalmazott nyelvészeti irányzatok megjelenését jelzik. Az alkalmazott nyelvészeti konferenciák így egy „fejlődési szenzor” szerepét tölthetik be, jelezhetik a várható változásokat. A hatodik és a hetedik konferencián az interkulturális kommunikáció témájából jelentkeztek legtöbben előadásra (Hidasi, 1998, pp. 28-31).

A MANYE rövidítés az 1998-as szombathelyi VIII. Magyar Alkalmazott Nyelvészeti Konferencia kötetében került fel először a konferenciakötet borítójára (Kohn \& Balaskó, 1999). Ennek a konferenciának az előkészítése során született meg a MANYE logója, amelyet kis változtatásokkal azóta is használ az egyesület. Azóta is a MANYE rövidítés szerepel a konferenciák felhívásaiban és konferenciák köteteinek címlapján. Mivel a korábbi konferenciákon a résztvevők száma folyamatosan 400 körül volt, az egyesület elnöke, a szombathelyi konferencia után, 1998-ban javasolta, hogy konferencia helyett ezután kongresszusnak nevezzük az alkalmazott nyelvészek évente megismétlődő találkozóit. Ezzel a két lépéssel ért véget az útkeresés, és kezdődött az egyesület életének következő szakasza, melyet a konszolidáció időszakának nevezhetünk.

\section{A konszolidáció időszaka}

\section{A MANYE-kongresszusok folyamatossága}

A döntés a kongresszussá való átnevezésről nem volt alaptalan, mert mint a Veszprémben rendezett IX. Magyar Alkalmazott Nyelvészeti Kongresszusnak a programfüzetben megjelent részvételi listája tanúskodik róla, 1999. április 8-10-ig 465 szakember érezte fontosnak, hogy ott legyen Veszprémben, mert ott olyan ismereteket szerezhet, és olyan szakmai kapcsolatokra tehet szert, amelyek pályája során fontosak lesznek.

De hogyan lett egyszerre ilyen sok embernek fontos az alkalmazott nyelvészet? Az egyik magyarázat szintén Szépe György nevéhez füződik, aki a pécsi, akkor Janus Pannonius Tudományegyetem Tanárképző Karának Nyelvi és Kommunikációs Intézetében 1996-ban elindította az alkalmazott nyelvészeti doktori programot, mely iránt óriási volt az érdeklődés. Minden nyelvszakos tanár számára, aki nem akart irodalommal vagy elméleti nyelvészettel foglalkozni, végre lehetővé vált, hogy a legtágabban vett alkalmazott nyelvészeti területek közül választhasson magának doktori témát a szaknyelvkutatástól a nyelvpolitikán keresztül a számítógépes nyelvészetig. Fóris Ágota 2013-ban a Modern Nyelvoktatásban megjelent cikkében rendkívül érzékletesen írta le azt a pezsgő szellemi légkört, amely a pécsi doktori képzést jellemezte. Évente 40-50 jelentkezőt is vonzott ez a szellemi mühely, nekik ideális terep volt a MANYE-kongresszusokon való részvétel a bemutatkozásra és a tapasztalatszerzésre.

A konszolidáció korszakának jellegzetessége volt, hogy megszilárdult az a tradíció, hogy az egyes kongresszusok záróülésén mindig bejelentik a következő évi 
kongresszus színhelyét: MANYE X. (Székesfehérvár, 2000), MANYE XI. (Pécs, 2001) MANYE XII. (Szeged, 2002), MANYE XIII. (Györ, 2003), MANYE XIV. (Nyíregyháza, 2004), MANYE XV. (Miskolc, 2005), MANYE XVI. (Gödöllő, 2006), MANYE XVII. (Siófok, 2007), MANYE XVIII. (Budapest Balassi Bálint Intézet, 2008), MANYE XIX. (Eger, 2009), MANYE XX. (Debrecen, 2010), MANYE XXI. (Szombathely, 2011), MANYE XXII. (Szeged, 2012), MANYE XXIII. (Budapest, 2013), MANYE XXIV. Kolozsvár, 2014), MANYE XXV. (Budapest PPKE, 2015).

Minden egyes kongresszusról és tematikai változatosságukról beszámolni lehetetlenség, de egy-két jellegzetesség talán kiemelhető. Az 1999-es veszprémi kongreszszuson adott a MANYE-választmány először Brassai Sámuel-díjat. A díjazott Papp Ferenc akadémikus, a számítógépes nyelvészet magyarországi úttöröje volt. A 2000es székesfehérvári kongresszuson az egyesület választmánya Szépe Györgynek ítélte a Brassai-díjat. A 2001-es pécsi kongresszus volt a legnagyobb létszámú (500-nál is többen jelentkeztek), mert akkor ünnepelte az egyesület Szépe György 70. születésnapját. A 2004-es nyíregyházi konferencián adott a MANYE választmánya elöször a „tiszteleti tag” elismerést. Szende Aladár kapta posztumusz, a lánya vette át. A 2008as budapesti Balassi intézeti kongresszuson mondott le 18 év után Szépe György a MANYE elnökségéről, és adta át az elnökséget Klaudy Kingának.

A 2010-es debreceni kongresszuson ünnepelte az egyesület a MANYE 20 éves jubileumát. Ezt a kongresszust az egyesület első Brassai-díjasa, Papp Ferenc akadémikus emlékének szenteltük (1930-2001), aki az MTA Alkalmazott Nyelvészeti Bizottsága elnökeként 1990-ben az MTA részéről elindította az alkalmazott nyelvészeti konferenciák sorozatát. Ennek a kongresszusnak a záróülésén Szépe György (1930-2012) tekintett vissza az elmúlt húsz évre, és elöadásának végén egészségi állapotára hivatkozva el is búcsúzott a tagságtól (Szépe, 2010, pp. 50-56). A 2013-as budapesti kongresszust végre az ELTE rendezte, amit Szépe György régen szorgalmazott, de mivel az ELTE-n nyolc tanszék részvételének összehangolására volt szükség a rendezéshez, erre a feladatra, amit végül Ladányi Mária nagyszerüen megoldott, sokáig nem volt jelentkező. Ezen a kongresszuson Klaudy Kingát Prószéky Gábor váltotta fel az elnöki tisztségben, amelyet azóta is betölt. A 2014-es kolozsvári kongresszus volt az első határon kívül rendezett kongresszus. A 2015-ös kongresszus újra jubileumi volt, a 25. A kongresszusnak az új elnök munkahelye, a Pázmány Péter Katolikus Egyetem Információs Technológiai és Bionikai Kara adott helyszínt. A nyitó plenáris előadáson Prószéky Gábor abból a szempontból tekintette át az elmúlt 25 évben végbement változásokat, hogy az alkalmazott nyelvészet különböző területein miként váltak egyre nélkülözhetetlenebbé a nyelvtechnológiai alkalmazások.

\section{A Brassai-dijj és a tiszteleti tagság}

1999-ban az egyesület vezetősége és választmánya díjat alapított kiemelkedő tagjai tevékenységének elismerésére. A díjat a nagy erdélyi polihisztor, Brassai Sámuel munkásságára emlékezve Brassai Sámuel-díjnak nevezték el. Az indoklás a következőképpen hangzik: „Brassai Sámuel-díj adományozható mindazoknak, akik az alkalmazott nyelvészet területén kiemelkedő teljesítményt nyújtanak, akik a MANYE tevékenységében az egyesület tagjaként aktívan részt vesznek, illetve mindazoknak a magyar és nem magyar állampolgároknak, akik az Egyesület tevékenységét nagy mértékben támogatják." 
A díjazott oklevelet kap, és egy $70 \mathrm{~mm}$ széles és $6 \mathrm{~mm}$ vastag köralakú ezüst plakettet, melynek tervezője Lugossy László, kivitelezője Halmágyi Róbert ötvösmüvész. A plakett egyik oldalán Brassai Sámuel arcképe, valamint születésének és halálának évszáma található, a másikon az egyesület neve. A díjazottat az előző három év Brassai-díjasainak jelölése alapján a választmány titkos szavazással választja. A dij átadására a kongresszusok nyitó plenáris ülésén kerül sor, az átadást követően valamelyik pályatárs tart laudációt, amely felkerül az egyesület honlapjára. A díjazott a következő kongreszszus nyitó plenáris ülésén Brassai-előadást tart. A Brassai-díjjal kapcsolatos ceremónia részletei (a laudáció és a Brassai-előadás tartása) az évek során fokozatosan alakultak ki.

Következzen a Brassai-díjasok névsora, és a díj átadásának éve: Papp Ferenc (1999), Szépe György (2000), Székely Gábor (2001), Klaudy Kinga (2002), Lengyel Zsolt (2003), Gósy Mária (2004), Prószéky Gábor (2005), Hidasi Judit (2006), Heltai Pál (2007), Bárdos Jenő (2008), Bakonyi István (2009), Cs. Jónás Erzsébet (2010), Sturcz Zoltán (2011), Szőllősy- Sebestyén András (2012), Fóris Ágota (2013), Tóth Szergej (2014), Kis Ádám (2015), Medgyes Péter, Sárdi Csilla (2017), Dróth Júlia (2019).

A ,tiszteleti tagság” a másik elismerés, amelyet az egyesület adományoz. Ezt azok kapják, akik tudományos munkásságukkal hozzájárultak az alkalmazott nyelvészet fejlődéséhez, akár az egyesületen belül, akár az egyesületen kívül. A tiszteleti tagnak járó oklevelet a jelölt az éves közgyülés elején kapja meg laudáció kíséretében.

Következzen a tiszteleti tagok névsora és a dij átadásának éve: Szende Aladár (2004), Hell György (2005), Magay Tamás (2006), Hegedűs József (2007), Dezső László (2008), Buday László (2009), Petőfi S. János (2010), Péntek János (2011), Fodor István (2012), Elekfi László (2013), Simigné Fenyő Sarolta (2014), Stephanides Éva (2015), Horlay György (2016), Székely Gábor (2017), Cs. Jónás Erzsébet (2018), Borgulya Istvánné (2019). Ezeknek a kiváló alkalmazott nyelvészeknek a listájára a MANYE méltán büszke lehet.

\section{A kongresszusi kiadványok színvonalának fejlesztése}

A vándorkongresszusi müfaj előnye, hogy minden évben más oktatási intézmény vállalja a szervezést, és a helyi szervezők csapatának összeállítása mindig újabb és újabb érdeklődőket vonz az alkalmazott nyelvészek körébe. Hátránya volt az első korszakban, hogy a kongresszusi kiadványok igen eltérő színvonalúak és formátumúak voltak (Székely, 1991; Klaudy, 1993; Annus, Bárdos \& Lengyel, 1994; Aradi, Sturcz \& Szőllősy, 1995; Lengyel \& Navracsics, 1996; Székely \& Cs. Jónás, 1997; Polyák, 1998; Balaskó \& Kohn, 1999). Az 1993-as miskolci konferencia anyagát (Klaudy, 1993) akárcsak az elsőét, egyszerüen befényképeztük a kötetbe, mert még nem volt mindenkinek lehetősége szövegszerkesztővel dolgozni, és e-mailen küldeni az előadását. Ez a technika a hivatkozási rendszer egységesítését is akadályozta. Az 1998-as szombathelyi konferencia záróülésén javasoltam, hogy egységes hivatkozási rendszert vezessünk be a kongresszusi kötetekben. A MANYE hivatkozási útmutatója az angol Harvard „Name and Date” rendszere alapján készült, felkerült az egyesület honlapjára (Klaudy 1999), és a további kongresszusi kötetekben a szerzőknek már az egységes MANYE hivatkozási rendszert kellett használni (Bartha \& Stephanides, 2001; Fóris, Kárpáti \& Szücs, 2002; Tóth, 2003; Bakonyi \& Nádai, 2004). 
A konszolidáció időszakához tartozik a MANYE kongresszusi kötetek külső megjelenésének, azaz borítótervének, gerincének és címnegyedívének egységesítése. Fóris Ágota intézte az OSZK-ban, hogy a MANYE-kongresszusok előadásait sorozatként tartsák nyilván, és saját ISSN-számot kapjanak az ISBN-szám mellé, amellyel addig is rendelkeztek. A sorozatterv kialakításában én is részt vettem az egységes borítóterv és a címnegyedív megtervezésével, amelyet azután minden kongresszus szervezői megkaptak a kötetek összeállítása elött. Az első ilyen egységesített sorozatterv szerint készült kötet az 2004-es nyíregyházi kongresszus előadásainak kétkötetes kiadványa volt (Cs. Jónás \& Székely, 2015), az utolsó a 2014-es kolozsvári konferenciáé (Benő, Fazekas \& Zsemlyei, 2015).

Akinek a könyvtárában egymás mellett állnak a könyvespolcon a kongresszusi kötetek, láthatják, hogy 2004 után milyen változás következett be a kötetek külalakjában, és apróbb eltérésektől eltekintve hasonlóan elegáns kötetekben jelentek meg az előadások. A sorozat neve: A MANYE Kongresszusok Előadásai Vol. 1. ISSN szám: 1786-545X. Egyetlen szépséghibája lett a sorozatnak: azt nem sikerült elérni, hogy visszafelé is sorozatnak minősítsék a konferenciaköteteket, így a XIV. MANYE Kongresszus Előadásai lett az első kötet. Ez a rendszer sikeresen működött egészen 2015-ig a Vol. 11.-ig (Vol.1.: Cs. Jónás \& Székely, 2005; Vol.2.: Klaudy \& Dobos, 2006; Vol. 3.: Heltai, 2007; Vol. 4.: Sárdi, 2008; Vol. 5.: Nádor, 2009; Vol. 6.: Zimányi, 2010; Vol. 7.: Boda \& Mónos, 2011; Vol. 8.: Horváthné Molnár \& Sciacovelli, 2012; Vol. 9.: Tóth, 2013; Vol. 10.: Ladányi, Vladár \& Hrenek, 2014, Vol. 11.: Benő, Fazakas \& Zsemlyei, 2015).

Sajnos a XXV. és a XXVI. MANYE Kongresszus előadásai nem a sorozat részeként jelentek meg (Reményi, Sárdi \& Tóth, 2016; Dombi, Farkas \& Guti, 2018). Más változás is történt: végleg lemondtunk a papírformában való megjelenésről, és a pécsi XXVI. MANYE Kongresszus tanulmánykötete (Dombi, Farkas \& Guti, 2018) már csak online formában jelent meg, és valószínűleg ez a megoldás marad a jövőben is. Azzal a különbséggel, hogy a budapesti XXVII. MANYE Kongresszus tanulmánykötetei (ugyanis több kötetben jelent meg a konferenciaanyag) visszakapták a sorozatjelleget és 2020-tól „A MANYE Kongresszusok Előadásai” sorozat újra folytatódik az Akadémiai Kiadónál immár online megjelenő kötetekkel, a sorozatszámozást megtartva (Vol. 12. Fóris \& Bölcskei, 2020).

A kongresszusi tanulmánykötetekbe az előadások nem automatikusan kerülnek be, hanem a különböző alkalmazott nyelvészeti szakterületek vezető szakembereinek lektori véleménye alapján. Az előadók az egyesület akkori honlapján nemcsak hivatkozási útmutatót kaptak, hanem ahhoz is segítséget kaptak, hogy miként szerkesszék tanulmánnyá az elhangzott előadásokat (Klaudy, 2006). Mivel a kötetek így is túlságosan vastagok lettek volna, egy ideig azt a gyakorlatot követtük, hogy a plenáris előadások és a bírálók által rangsorolt előadások első fele került csak nyomtatott kötetbe, a második fele a kötethez csatolt CD-mellékletként jelent meg. Mostanra, amikor a 30. évfordulót ünnepeljük, az online megjelenés ezt a gyakorlatot már feleslegessé tette.

Nemcsak a kongresszusi tanulmányköteteket igyekeztünk egységesíteni, hanem a különböző helyszíneken zajlott kongresszusok is egységes menetrend szerint zajlottak. Fóris Ágota 2007-ben készített ,,Segédlet a kongresszusok szervezéséhez” címü kiadványában összefoglalta az addigi tapasztalatokat a MANYE-kongresszusok elö- 
készítéséről, menetéről, és utómunkálatairól, és a későbbi kongresszusok szervezőinek ez fontos segítség volt. Különösen 2015-ig, amíg minden évben volt kongresszus, és nagyon rövid idő állt rendelkezésre a felkészüléshez.

\section{A vezetőség és a választmány}

Egy egyesület konszolidált müködéshez nemcsak az egyesület vezetőségének aktivitása és választmányának a lelkesedése szükséges, hanem elfogadott alapszabály, és az alapszabály szerinti funkciók betöltése és kifogástalan ellátása. A MANYE 1990-ben elfogadott alapszabályának több módosítása is volt, mindegyiket megvitatta és jóváhagyta a közgyủlés. A tisztségviselöket a közgyülés választja meg ötéves ciklusokra. Az egyesület elnöke 1990-től 2008-ig Szépe György volt, a következő ciklusban Klaudy Kinga, majd Prószéky Gábor lett az elnök, aki 2013 óta tölti be ezt a szerepet. Eddig nem volt szó a vezetőség többi tagjáról, az alelnökökről, a főtitkárról, a pénztárosról, a számvizsgáló bizottság elnökéről és tagjairól, akiknek munkája a külső szemlélő számára nem látványos, de az egyesület számára létfontosságú.

Az 1990-es alakuló ülésen megválasztott tisztségviselők a jegyzőkönyv szerint (GJDOK1) a következők voltak: elnök: Szépe György (Pécs), alelnökök: Bárdos Jenő (Veszprém), Bassola Péter (Szeged), főtitkár: Gárdus János (Miskolc), fötitkárhelyettes: Szanyi Gyula (Debrecen), titkár: Basel Péter (Budapest, TIT), pénztáros: Tóth Pál (Budapest, Közgazdasági Egyetem), szerkesztő: Horváth Iván (Budapest, ITK). Ez az utóbbi funkció később megszünt. A tisztségviselők melletti városnevek mutatják az alakuló szervezet országos jellegét. Az elnök után a főtitkári funkció a legfontosabb. Az első fötitkárt, Gárdus Jánost (1990-1993) Lengyel Zsolt követte (1993-2002), majd több cikluson keresztül Szőllősy-Sebestyén András (2002-2018) volt a főtitkár, 2018 óta pedig Sárdi Csilla tölti be ezt a funkciót. A főtitkár munkáját főtitkárhelyettes és titkár vagy titkárok segítik. Az alábbi táblázat szemlélti a tisztségviselők funkcióit az utolsó négy ciklusban.

\section{1. táblázat}

A MANYE tisztségviselői a legutóbbi négy ciklusban

\begin{tabular}{|c|c|c|c|c|}
\hline & 2003-2008 & 2008-2013 & 2013-2018 & 2018-2023 \\
\hline Elnök & Szépe György & Klaudy Kinga & Prószéky Gábor & Prószéky Gábor \\
\hline $\begin{array}{l}\text { Elnöki ta- } \\
\text { nácsadó }\end{array}$ & & Fóris Ágota & & \\
\hline Alelnökök & $\begin{array}{l}\text { Bassola Péter } \\
\text { Bárdos Jenő } \\
\text { Klaudy Kinga }\end{array}$ & $\begin{array}{l}\text { Lengyel Zsolt } \\
\text { Székely Gábor } \\
\text { Tóth Szergej } \\
\text { Medgyes Péter } \\
(2012-2014)\end{array}$ & $\begin{array}{l}\text { Bárdos Jenő } \\
\text { Fóris Ágota } \\
\text { Klaudy Kinga } \\
\text { Székely Gábor } \\
\text { Medgyes Péter } \\
(2012-2014)\end{array}$ & $\begin{array}{l}\text { Fóris Ágota } \\
\text { Károly Krisztina } \\
\text { Klaudy Kinga } \\
\text { Szőllősy-Sebestyén } \\
\text { András } \\
\text { Tóth Szergej }\end{array}$ \\
\hline Főtitkár & $\begin{array}{l}\text { Szöllősy-Sebestyén } \\
\text { András }\end{array}$ & $\begin{array}{l}\text { Szöllősy-Sebestyén } \\
\text { András }\end{array}$ & $\begin{array}{l}\text { Szöllősy-Sebestyén } \\
\text { András }\end{array}$ & Sárdi Csilla \\
\hline $\begin{array}{l}\text { Fötitkár- } \\
\text { helyettes }\end{array}$ & Székely Gábor & Gecső Tamás & Sárdi Csilla & Fata Ildikó \\
\hline
\end{tabular}




\begin{tabular}{|l|l|l|l|l|}
\hline Titkár & Tóth Szergej & Bódi Zoltán & $\begin{array}{l}\text { Bódi Zoltán } \\
\text { Fata Ildikó }\end{array}$ & $\begin{array}{l}\text { Bódi Zoltán (2018- } \\
2020) \\
\text { Sólyom Réka } \\
\text { Seidl-Péch Olivia } \\
(2020-)\end{array}$ \\
\hline $\begin{array}{l}\text { Külügyi } \\
\text { titkár }\end{array}$ & $\begin{array}{l}\text { Hidasi Judit } \\
(2006 \text {-tól) }\end{array}$ & Hidasi Judit & Hidasi Judit & Hidasi Judit \\
\hline Pénztáros & Fóris Ágota & Sárdi Csilla & Sárdi Csilla & Fata Ildikó \\
\hline $\begin{array}{l}\text { Számvizs- } \\
\text { gáló Bizott- } \\
\text { ság elnöke }\end{array}$ & Kis Ádám & Kis Ádám & Kis Ádám & Kis Ádám \\
\hline $\begin{array}{l}\text { Számvizs- } \\
\text { gáló Bizott- } \\
\text { ság tagjai }\end{array}$ & $\begin{array}{l}\text { Répási Györgyné } \\
\text { Salánki Ágnes }\end{array}$ & $\begin{array}{l}\text { Répási Györgyné } \\
\text { Salánki Ágnes }\end{array}$ & $\begin{array}{l}\text { Pusztai Varga Ildikón } \\
\text { Salánki Ágnes }\end{array}$ & $\begin{array}{l}\text { Pusztai Varga Ildikó } \\
\text { Bérces Edit }\end{array}$ \\
\hline
\end{tabular}

A külügyi titkár tisztségét először Kohn János (1941-1999) töltötte be, aki a német alkalmazott nyelvészeti egyesületekkel tartotta a kapcsolatot, majd halála után sokáig betöltetlen volt ez a funkció. 2006 óta ciklusokon átívelően Hidasi Judit a külügyi titkár. Ö tartja a kapcsolatot a FIPLV-vel (Fédération Internationale des Professeurs des Langues Vivantes/International Federation of Language Teacher Associations), amelynek a MANYE alakulása óta tagja, és az ő szervezőmunkájának köszönhető, hogy Szépe György 2008-ban és Szőllősy Sebestyén András 2017-ben átvehette a „FIPLV International Award” kitüntetést.

Mivel az egyesület a tagdíjakból tartja fenn magát, a pénztárosé az egyik legfontosabb funkció. A tagdíjfizetés kezdettől fogva létfontosságú volt, illetve csak lett volna, mert a vizsgált jegyzőkönyvekből kiderül, milyen nehezen ment a tagdíj megállapítása és beszedése. Még az 1996-os közgyülésen is csak javaslat az 500 Ft/félév tagsági díj (GJDOK 12). A pénztáros tisztet kezdetben Grünwald Imre töltötte be, majd Navracsics Judit és Fóris Ágota lett a pénztáros (utóbbi 2002-2008-ig, erre az időszakra vonatkozóan lásd Fóris 2013).

2008 után több cikluson keresztül Sárdi Csilla töltötte be ezt a funkciót, és annak ellenére, hogy az éves tagdíj fokozatosan emelkedett (most $5000 \mathrm{Ft}$ ), sikerült rábírnia a tagságot a rendszeres tagdífizetésre. Különösen a kongresszusokon való kedvezményes részvétel növelte a tagdíjfizetési hajlandóságot. A számvizsgáló bizottság elnöke több cikluson keresztül Kis Ádám volt. A számvizsgáló bizottság helyét most 2020ban felügyelőbizottság veszi át, amelynek Bódi Zoltán az elnöke, tagjai: Pusztai Varga Ildikó és Malaczkov Szilvia. Az alelnökök száma nincs korlátozva, ciklusonként változtak: Bassola Péter, Bárdos Jenő, Fóris Ágota, Károly Krisztina, Klaudy Kinga, Lengyel Zsolt, Székely Gábor, Tóth Szergej, Szőllösy Sebestyén András töltöttek és/ vagy töltenek be alelnöki szerepet. Medgyes Péter mint a Modern Nyelvoktatás címü folyóirat föszerkesztője volt alelnök 2012-2014-ig. Mint látjuk, ugyanazok a személyek különböző tisztségeket is betöltöttek és betöltenek. A vezetőség tagjainak és a választmány ciklusonként cserélődő negyven tagjának neve az egyesület honlapján található meg. A MANYE tisztségviselői csapata az alábbi tablón látható. 
1. ábra

A MANYE vezetöségének tagjai a legutóbbi négy ciklusban
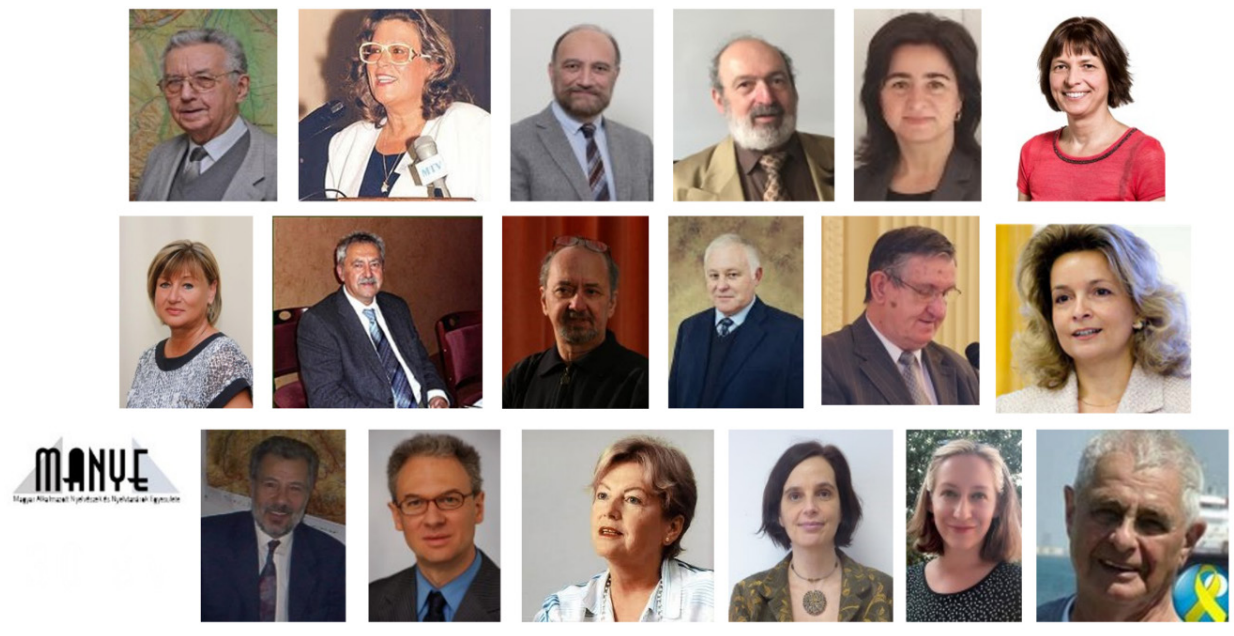

A felső sorban balról jobbra: Szépe György, Klaudy Kinga, Prószéky Gábor, Szőllősy-Sebestyén András, Fóris Ágota, Sárdi Csilla. A középső sorban balról jobbra: Navracsics Judit, Lengyel Zsolt, Tóth Szergej, Bárdos Jenő, Székely Gábor, Károly Krisztina. Az alsó sorban balról jobbra: Bassola Péter, Bódi Zoltán, Hidasi Judit, Fata Ildikó, Sólyom Réka, Kis Ádám.

\section{Mit képvisel a MANYE? Kiket vár tagjai közé?}

A MANYE az alkalmazott nyelvészet tág felfogását képviseli. Az idegennyelv-oktatás módszertanán kívül idetartozik az anyanyelv oktatása, a magyar mint idegen nyelv oktatása, a pszicholingvisztika, a szociolingvisztika, a terminológia, a lexikográfia, az interkulturális kommunikáció, a fordítás és tolmácsolás kutatása, a számítógépes nyelvészet stb., vagyis minden olyan terület, ahol a nyelvtudományi kutatás a társadalom mindennapos tevékenysége során felmerülő nyelvi problémák megoldásában segíteni tud. Tagjai közé várja mindazokat a nyelvtanárokat, fordítókat, tolmácsokat, lektorokat, szerkesztőket, terminológusokat, akik napi rutintevékenységükön túl kutatással is foglalkoznak.

\section{Mit nyújt a MANYE a tagjainak?}

Az alkalmazott nyelvészek szakmai közösségéhez való tartozás tudatát, ahol a tagok egy információs szakmai hálózat részei is egyben, és ahol a hosszú évek alatt a szakmai kapcsolatok gyakran barátságokká formálódnak. A tagok rendszeresen értesülnek a szakmai eseményekről, kedvezményesen részt vehetnek a kongresszusokon és a többi szakmai eseményen, hasznos szakmai kapcsolatokat köthetnek, előadásaikról visszajelzést kaphatnak tapasztaltabb pályatársaiktól, publikálhatnak az egyesület folyóiratában, a Modern Nyelvoktatásban és a kongresszusi kötetekben. Mindkettő sze- 
repel a Magyar Tudományos Akadémia Nyelvtudományi Bizottsága által jóváhagyott publikációs fórumok sorában.

A MANYE 30 év óta mindmáig Szépe Györgynek, az egyesület alapítójának a szellemében tevékenykedik. Nyitott, befogadó, igényes, inspiratív és innovatív egyesület. Nagy kincs. Örizzük meg!

\section{IRODALOM}

Fóris, Á. (2009). Magyar Alkalmazott Nyelvészeti Kongresszus. Segédlet a kongresszusok szervezéséhez. Kézirat. MANYE.

Fóris, Á. (2013). Szépe György és a pécsi alkalmazott nyelvészeti műhely. Modern Nyelvoktatás, 19(12), 85-92.

Hidasi, J. (2008). Az alkalmazott nyelvészeti konferenciák színeváltozása. In Polyák, I. (Ed.), A VII. Országos Alkalmazott Nyelvészeti Konferencia elöadásai I-II. kötet (pp. 28-31). Külkereskedelmi Föiskola.

Klaudy, K. (1999, frissítve: 2011). MANYE hivatkozási és szerkesztési útmutató. http://www.kjf.hu/ manye/konalttud.html (2020.03.05.)

Klaudy, K. (2006). Jótanácsok kezdő MANYE-előadók számára az előadás írott változatának elkészítéséhez. http://www.kjf.hu/manye/konalttud.html (2020.03.05.)

Szépe, Gy. (1994). Az alkalmazott nyelvészet kutatásáról és oktatásáról. In Klaudy K. (Ed.), A III. Magyar Alkalmazott Nyelvészeti konferencia elöadásai (pp. 17-28.)

Szépe, Gy. (2011). A Magyar Alkalmazott Nyelvészek és Nyelvtanárok Egyesületének (MANYE) 20 évében. In Boda, I. K. \& Mónos, K. (Eds.) „Az alkalmazott nyelvészet ma: innováció, technológia, tradíció”. A MANYE Kongresszusok Előadásai. Vol. 7. No. 1. (pp. 50-56), MANYE - Debreceni Egyetem.

\section{Források}

Gárdus János hagyatékából származó dokumentumok (1990-1995):

GJDOK 1 (1990. május 11.) Jegyzőkönyv a TIT Országos Idegennyelv-oktatási Választmány kibővített vezetőségi üléséről, amely egyúttal a Magyarországi Nyelvoktatók Egyesületének alakuló ülése

GJDOK 2 (1990. május-december) Eredeti belépési nyilatkozatok (53 db)

GJDOK 3 (1990. augusztus 8.) Szépe György elnök levele Gárdus János főtitkárnak az egyesület miskolci bejegyzéséről

GJDOK 4 (1990. október 24.) Gárdus János főtitkár meghívója a Magyarországi Nyelvoktatók Egyesületének vezetőségi ülésére

GJDOK 5 (1993. október 3.) Jegyzőkönyv a Magyarországi Nyelvoktatók Egyesülete közgyüléséröl

GJDOK 6 (1994. április 8.) Jegyzőkönyv a Magyarországi Nyelvoktatók Egyesülete vezetőségi üléséről GJDOK 7 (1994. május 16.) Jegyzőkönyv a Magyarországi Nyelvoktatók Egyesületének közgyüléséről GJDOK 8 (1994. november 22.) Jegyzőkönyv a Magyar Alkalmazott Nyelvészek és Nyelvtanárok Egyesületének titkársági üléséről

GJDOK 9 (1995. január 3.) Jegyzőkönyv a MANYE (sic!) vezetőségi üléséről

GJDOK 10 (1995. április 20.) Jegyzőkönyv a MANYE (sic!) vezetőségi üléséről

GJDOK 11 (1995. április 22.) Jegyzőkönyv a MANYE (sic!) közgyűléséről 


\section{Az MTA Alkalmazott Nyelvészeti Bizottságának dokumentumai (1990-1995):}

MTADOK 1 (1990. október 18.) Papp Ferenc akadémikus meghívója az MTA Alkalmazott Nyelvészeti Bizottság 1990. november 1-i alakuló ülésére

MTADOK 2 (1990. november 1.) Az MTA Alkalmazott Nyelvészeti Bizottság alakuló ülésének jegyzőkönyve

MTADOK 3 (1991. június 14.) Papp Ferenc akadémikus meghívója az MTA Alkalmazott Nyelvészeti Bizottságának 1991. július 5-i ülésére (napirenden a nyíregyházi és a szegedi alkalmazott nyelvészeti konferencia)

MTADOK 4 (1991. július 5.) Emlékeztető az Alkalmazott Nyelvészeti Bizottság 1991. július 5-i üléséről (napirenden beszámoló az I. Magyar Alkalmazott Nyelvészeti Konferenciáról)

MTADOK 5 (1992. március 25.) Jelentés a szegedi II. Magyar Alkalmazott Nyelvészeti Konferencia elökészületeiröl

MTADOK 6 (1992. március 30.) Papp Ferenc akadémikus meghívója az Alkalmazott Nyelvészeti Bizottság április 16-i ülésére (napirenden beszámoló a szegedi II. Alkalmazott Nyelvészeti Konferencia szervezésének állásáról)

MTADOK 7 (1993. május 13.) Papp Ferenc akadémikus meghívója az Alkalmazott Nyelvészeti Bizottság 1993. június 4-i ülésére (napirenden beszámoló a miskolci III. Alkalmazott Nyelvészeti Konferenciáról)

MTADOK 8 (1994. október 21.) Jegyzőkönyv az MTA Alkalmazott Nyelvészeti Bizottság üléséröl (napirenden beszámoló a budapesti IV. Országos Alkalmazott Nyelvészeti Konferenciáról)

MTADOK 9 (1995. május 3.) Papp Ferenc akadémikus meghívója az Alkalmazott Nyelvészeti Bizottság 1995. május 19-i ülésére (napirenden beszámoló a veszprémi V. Magyar Alkalmazott Nyelvészeti Konferenciáról)

\section{APPENDIX}

\section{A Magyar Alkalmazott Nyelvészeti Konferenciák és Kongresszusok színhelyei és szerkesztett kötetei}

I. Magyar Alkalmazott Nyelvészeti Konferencia. Nyíregyháza: Bessenyei György Tanárképző Főiskola, 1991. május 3-4.

Kiadvány:

Székely Gábor (szerk.) 1991. Elsö Magyar Alkalmazott Nyelvészeti Konferencia. I-II. Nyíregyháza: Nyíregyházi Föiskola.

II. Magyar Alkalmazott Nyelvészeti Konferencia. Szeged: Juhász Gyula Tanárképző Föiskola, 1992. május 1-2.

Kiadvány:

Annus Gábor - Bárdos Jenő - Lengyel Zsolt (szerk.) 1994. II. Magyar Alkalmazott Nyelvészeti Konferencia. Veszprém: Veszprémi Egyetemi Kiadó.

III. Magyar Alkalmazott Nyelvészeti Konferencia. Miskolc: Miskolci Egyetem, 1993. április 2-3.

Kiadvány:

Klaudy Kinga (szerk.) 1993. III. Magyar Alkalmazott Nyelvészeti Konferencia. I-II. Miskolc: Miskolci Egyetem. 
IV. Országos Alkalmazott Nyelvészeti Konferencia. „Többnyelvűség az oktatásban és a kutatásban”. Budapest: Budapesti Müszaki Egyetem, 1994. április 7-9.

Kiadvány:

Aradi András - Sturcz Zoltán - Szöllősy-Sebestyén András (szerk.) 1994. IV. Országos Alkalmazott Nyelvészeti Konferencia. Többnyelvüség az oktatásban és a kutatásban. I-II. Folia practico-linguistica XXIV. évf. Budapest: BME Természet- és Társadalomtudományi Kar Nyelvi Intézet.

V. Magyar Alkalmazott Nyelvészeti Konferencia. „Európai és hazai dimenziók”. Veszprém: Veszprémi Egyetem, 1995. április 20-22.

Kiadvány:

Lengyel Zsolt - Navracsics Judit (szerk.) 1995. Ötödik Magyar Alkalmazott Nyelvészeti Konferencia. Veszprém: Veszprémi Egyetem.

VI. Országos Alkalmazott Nyelvészeti Konferencia. „Nyelvek és nyelvoktatás a Kárpát-medencében". Nyíregyháza: Bessenyei György Tanárképző Főiskola, 1996. április 2-4. Kiadvány:

Székely Gábor - Cs. Jónás Erzsébet (szerk.) 1996. Nyelvek és nyelvoktatás a Kárpát-medencében. VI. Országos Alkalmazott Nyelvészeti Konferencia. Nyíregyháza: Bessenyei György Könyvkiadó.

VII. Magyar Alkalmazott Nyelvészeti Konferencia. „Európa kapujában. Kultúrák találkozása - interkulturális tanulmányok”. Budapest: Külkereskedelmi Főiskola, 1997. április 3-5.

Kiadvány:

Polyák Ildikó (szerk.) 1997. VII. Magyar Alkalmazott Nyelvészeti Konferencia. I-II. Budapest: Külkereskedelmi Főiskola.

VIII. Magyar Alkalmazott Nyelvészeti Konferencia. „A nyelv mint szellemi és gazdasági tőke" Szombathely, Berzsenyi Dániel Tanárképző Főiskola, 1998. április 16-18. Kiadvány:

Balaskó Mária - Kohn János (szerk.) 1999. A nyelv mint a szellemi és gazdasági tỏke. A VIII. Magyar Alkalmazott Nyelvészeti Konferencia elöadásainak gyüjteményes kiadása. I-III. Szombathely: BDTF Alkalmazott Nyelvészeti Tanszék.

IX. Magyar Alkalmazott Nyelvészeti Kongresszus. „Nyelvi kihívások a harmadik évezredben" Veszprém, Veszprémi Egyetem, 1999. április 8-10.

Kiadvány:

Lengyel Zsolt - Navracsics Judit - Nádasi Edit (szerk.) 1999. Nyelvi kihívások a harmadik évezredben. IX. Magyar Alkalmazott Nyelvészeti Kongresszus. Veszprém. Veszprémi Egyetem, Alkalmazott Nyelvészeti Tanszék (absztrakt-gyüjtemény).

X. Magyar Alkalmazott Nyelvészeti Kongresszus. „A nyelv szerepe az információs társadalomban”. Székesfehérvár: Kodolányi János Föiskola, 2000. április 18-20.

Kiadvány:

Bartha Magdolna - Stephanides Éva (szerk.) 2001. A nyelv szerepe az információs társadalomban. Összefoglalók kötete. Székesfehérvár: Kodolányi János Főiskola. 
Bartha Magdolna - Stephanides Éva (szerk.) 2001. A nyelv szerepe az információs társadalomban. A X. Magyar Alkalmazott Nyelvészeti Kongresszus elöadásainak válogatott gyüjteménye. Székesfehérvár: Kodolányi János Főiskola.

XI. Magyar Alkalmazott Nyelvészeti Kongresszus. „A nyelv nevelő szerepe” Pécs: Pécsi Tudományegyetem, 2001. április 17-19.

Kiadványok:

Fóris Ágota - Kárpáti Eszter - Szücs Tibor (szerk.) 2002. A nyelv nevelö szerepe. A XI. Magyar Alkalmazott Nyelvészeti Kongresszus elöadásainak válogatott gyüjteménye. Pécs: Lingua Franca Csoport.

Pusztay János (szerk.) 2002. Kontrasztív nyelvészeti tanulmányok. (Colloquia Contrastiva, Tomus IX.) Szombathely: BDTF Kiadó.

Drescher J. Attila - Herr Judit (szerk.) 2003. A MANYE XI. (pécsi) és XII. (szegedi) kongresszusa nemzetiségi és nyelvpolitikai tárgyú előadásaiból. (Szekszárdi Alkalmazott Nyelvészeti Füzetek 2.) Szekszárd-Pécs-Budapest: Pécsi Tudományegyetem Illyés Gyula Főiskolai Kar-MANYE.

Tóth Szergej - Földes Csaba - Fóris Ágota (szerk.) 2004. Lexikológiai és lexikográfiai látkép: Problémák, paradigmák, perspektívák. (Fasciculi Linguistici Series Lexicographica 3.) Szeged: Generália.

XII. Magyar Alkalmazott Nyelvészeti Kongresszus. „Nyelvek és kultúrák találkozása” Szeged: Szegedi Tudományegyetem, Juhász Gyula Tanárképző Főiskolai Kar, 2002. március 27-29.

Kiadványok:

Tóth Szergej (szerk.) 2003. Nyelvek és kultúrák találkozása. Összefoglalók kötete. Szeged: Szegedi Tudományegyetem.

Tóth Szergej (szerk.) 2003. Nyelvek és kultúrák találkozása. Szeged: Szegedi Tudományegyetem.

Székely Gábor (szerk.) 2003. Nyelvek és kultúrák találkozása. Kontrasztív nyelvészeti szekció. Nyíregyháza: Nyíregyházi Főiskola, Bölcsészettudományi és Mủvészeti Főiskolai Kar.

Drescher J. Attila - Herr Judit (szerk.) 2003. A MANYE XI. (pécsi) és XII. (szegedi) kongresszusa nemzetiségi és nyelvpolitikai tárgyú elöadásaiból. (Szekszárdi Alkalmazott Nyelvészeti Füzetek 2.) Szekszárd-Pécs-Budapest: Pécsi Tudományegyetem Illyés Gyula Főiskolai Kar-MANYE.

Tóth Szergej - Földes Csaba - Fóris Ágota (szerk.) 2004. Lexikológiai és lexikográfiai látkép: Problémák, paradigmák, perspektívák. (Fasciculi Linguistici Series Lexicographica 3.) Szeged: Generália.

XIII. Magyar Alkalmazott Nyelvészeti Kongresszus. „A többnyelvü Európa” Győr, Széchenyi István Egyetem, 2003. április 14-16. Kiadványok:

Bakonyi István - Nádai Julianna (szerk.) 2004. A többnyelvü Európa. Győr: Széchenyi István Egyetem, Idegen Nyelvi és Kommunikációs Tanszék.

Borgulya Istvánné (szerk.) 2004. Kultúraközi, szakmai és szervezeti kommunikáció. Pécs: Pécsi Tudományegyetem, Közgazdaságtudományi Kar.

Pusztay János (szerk.) 2004. Kontrasztív nyelvészeti tanulmányok. (Colloquia Contrastiva, Tomus XI.) Szombathely: BDF Kiadó.

Bartha Magdolna (szerk.) 2004. A XIII. MANYE Kongresszus szociolingvisztika szekciójának válogatott közleményei. Székesfehérvár: Kodolányi János Főiskola. 
XIV. Magyar Alkalmazott Nyelvészeti Kongresszus. „Nyelvek és nyelvoktatás Európa és a Kárpát-medence régióiban” Nyíregyháza, Nyíregyházi Föiskola. 2004. április 5-7.

Kiadvány:

Székely Gábor-Cs. Jónás Erzsébet (szerk.) 1996. Nyelvek és nyelvoktatás Európa és a Kárpát-medence régióiban. A XIV. Magyar Alkalmazott Nyelvészeti Konferencia elöadásai. A MANYE Kongresszusok Elöadásai Vol. 1. No. 1., No. 2. Nyíregyháza: Bessenyei György Könyvkiadó.

XV. Magyar Alkalmazott Nyelvészeti Kongresszus. „A nyelv világa és a világ nyelvei. Soknyelvüség a gazdaságban, a tudományban és az oktatásban.” Miskolc: Miskolci Egyetem. 2005. április 7-9.

Kiadványok:

Klaudy Kinga - Kegyesné Szekeres Erika (szerk.) 2005. A nyelv világa és a világ nyelvei. Soknyelvüség a gazdaságban, a tudományban és az oktatásban. Összefoglalók kötete. Miskolc: MANYE - Miskolci Egyetem.

Klaudy K. - Dobos Cs. (szerk.) A nyelv világa és a világ nyelvei. Soknyelvüség a gazdaságban, a tudományban és az oktatásban. A MANYE Kongresszusok Előadásai Vol. 2. No. 1., No. 2. Pécs-Miskolc: MANYE - Miskolci Egyetem.

XVI. Magyar Alkalmazott Nyelvészeti Kongresszus. „Nyelvi modernizáció. Szaknyelv, fordítás, terminológia” Gödöllő: Szent István Egyetem, 2006. április 10-12. Kiadványok:

Dróth Júlia (szerk.) 2007. „Nyelvi modernizáció. Szaknyelv, forditás, terminológia”. Összefoglalók kötete. Gödöllő: MANYE - Szent István Egyetem.

Heltai Pál (szerk.) 2007. „Nyelvi modernizáció. Szaknyelv, forditás, terminológia”. A MANYE Kongresszusok Elöadásai. Vol. 3. No. 1., No. 2. (CD mellékletben). Gödöllő: Szent István Egyetem.

XVII. Magyar Alkalmazott Nyelvészeti Kongresszus. „Kommunikáció az információs technológia korszakában”. Siófok: Kodolányi János Főiskola, 2007. április 19-21. Kiadvány:

Sárdi Csilla (szerk.) 2008. „Kommunikáció az információs technológia korszakában”. A MANYE Kongresszusok Előadásai. Vol. 4. No. 1., No. 2. (CD mellékletben) Pécs-Székesfehérvár: MANYE-Kodolányi János Főiskola.

XVIII. Magyar Alkalmazott Nyelvészeti Kongresszus. „A magyar mint európai és világnyelv". Budapest: Balassi Bálint Intézet, 2008. április 3-5.

Kiadvány:

Nádor Orsolya (szerk.) 2009. „A magyar mint európai és világnyelv”. A MANYE Kongresszusok Elöadásai. Vol. 5. Budapest: MANYE-Balassi Intézet.

XIX. Magyar Alkalmazott Nyelvészeti Kongresszus. „A tudomány nyelve - a nyelv tudománya”. Eger: Eszterházy Károly Főiskola, 2009. április 16-18. Kiadvány:

Zimányi Árpád (szerk.) 2010. „A tudomány nyelve - a nyelv tudománya”. A MANYE Kongresszusok Elöadásai. Vol. 6. No. 1., No. 2. (CD mellékletben). Budapest: MANYE - Balassi Intézet. 
XX. Magyar Alkalmazott Nyelvészeti Kongresszus. „Az alkalmazott nyelvészet ma: innováció, technológia, tradíció”. Debrecen: Debreceni Egyetem, 2010. augusztus $26-28$.

Kiadvány:

Boda István Károly - Mónos, Katalin (szerk.) 2011. „Az alkalmazott nyelvészet ma: innováció, technológia, tradició”. A MANYE Kongresszusok Elöadásai. Vol. 7. No. 1., No. 2. (CD mellékletben). Debrecen: MANYE - Debreceni Egyetem.

XXI. Magyar Alkalmazott Nyelvészeti Kongresszus. „Az alkalmazott nyelvészet regionális szerepe”. Szombathely: Nyugatmagyarországi Egyetem, 2011. augusztus 29-31. Kiadvány:

Horváthné Molnár Katalin - Sciacovelli, Donato Antonio (szerk.) 2012. „Az alkalmazott nyelvészet regionális szerepe”. A MANYE Kongresszusok Elöadásai. Vol. 8. No. 1., No. 2. (CD mellékletben). Budapest-Szombathely-Sopron: MANYE - Nyugatmagyarországi Egyetem.

XXII. Magyar Alkalmazott Nyelvészeti Kongresszus. „Alkalmazott nyelvészeti kutatások a Kárpát-medencében”. Szeged: Szegedi Tudományegyetem, 2012. április 12-14. Kiadvány:

Tóth Szergej (szerk.) 2013. „Alkalmazott nyelvészeti kutatások a Kárpát-medencében”. A MANYE Kongresszusok Előadásai. Vol. 9. Budapest-Szeged: Szegedi Egyetemi Kiadó.

XXIII. Magyar Alkalmazott Nyelvészeti Kongresszus. „Nyelv-társadalom-kultúra. Interkulturális és multikulturális perspektívák". Budapest: ELTE, 2013. március $26-28$.

Kiadvány:

Ladányi Mária - Vladár Zsuzsa - Hrenek Éva (szerk.) 2014. „Nyelv-társadalom-kultúra. Interkulturális és multikulturális perspektívák”". A MANYE Kongresszusok Elöadásai. Vol. 10. №. 1. №. 2. (CD mellékletben). Budapest: MANYE - Tinta Könyvkiadó.

XXIV. Magyar Alkalmazott Nyelvészeti Kongresszus. „Többnyelvűség és kommunikáció Kelet-Közép-Európában”. Kolozsvár: Babes-Bolyai Tudományegyetem, 2014. április 24-26.

Kiadvány:

Benő Attila - Fazakas Emese - Zsemlyei Borbála (szerk.) 2015. „Többnyelvüség és kommunikáció Kelet-Közép-Európában”. A MANYE Kongresszusok előadásai. Vol. 11. Kolozsvár: EME.

XXV. Magyar Alkalmazott Nyelvészeti Kongresszus. „Nyelv - Nyelvtechnológia Nyelvpedagógia: 21. századi távlatok”. Budapest: Pázmány Péter Katolikus Egyetem, 2015. március 30.-április 1.

Kiadvány:

Reményi Andrea Ágnes - Sárdi Csilla - Tóth Zsuzsa (szerk.) 2016. „Távlatok a mai magyar alkalmazott nyelvészetben". Budapest: Tinta Könyvkiadó. 
XXVI. Magyar Alkalmazott Nyelvészeti Kongresszus. „Aszimmetrikus kommunikáció - aszimmetrikus viszonyok". Pécs: Pécsi Tudományegyetem. 2017. augusztus 30.--szeptember 1.

Kiadvány:

Dombi Judit - Farkas, Judit - Guti Erika (szerk.) 2018. „Aszimmetrikus kommunikáció- aszimmetrikus viszonyok”. Budapest: Szak Kiadó. (www.manye.hu)

XXVII. Magyar Alkalmazott Nyelvészeti Kongresszus. „Nyelv, kultúra identitás. Alkalmazott nyelvészeti kutatások a 21. századi információs térben” Budapest: Károli Gáspár Református Egyetem, 2019. április 15-16.

Kiadványok:

Fóris Ágota - Bölcskei Andrea (főszerk.) 2020. „Nyelv, kultúra identitás. Alkalmazott Nyelvészeti kutatások a 21. századi információs térben”. A MANYE Kongresszusok Előadásai. Vol. 12. No. 1., No. 2., No. 3., No. 4., No. 5. Budapest: Akadémiai Kiadó. (https://mersz.hu/a-manye-kongresszusok-eloadasai) 